Małgorzata SIKORA-GACA

DOI : $10.14746 /$ pp.2019.24.4.1

Kazimierz Wielki University

ORCID ID: 0000-0001-5000-2694

Urszula KOSOWSKA

SOFRA Health Institute

ORCID ID: 0000-0002-9979-0422

\title{
Assessment of changes in the level of human capital in Poland in the context of the use of European funds for projects in the field of science and education contracted for implementation in 2004-2006
}

\begin{abstract}
The article presents the analysis of 2,947 projects in the area of science and education cofinanced by the Structural Funds in Poland in 2004-2006. It summarizes the investments co-financed by the European Regional Development Fund, the European Social Fund and the European Agricultural Guidance and Guarantee Fund. Data on 2,947 projects, with their regional division, have been verified. Thanks to this regional leaders have been distinguished in terms of the number of projects and raised funds in 2004-2006. Most importantly, the amount of the subsidy from the EU to projects in the area of science and education in Poland in the years 2004-2006 has been estimated per capita of individual region. These data were compared with the selected human capital development indicators in 2003, 2006, 2009 and 2012 to assess the impact of European funding in the field of science and education on human capital in Poland.
\end{abstract}

Key words: Poland, science and education, structural fund, human capital

\section{Introduction}

A ccession to the European Union has enabled Poland to participate in EU budget funds for the implementation of investments in various areas. One of the priority subjects that required intervention was the science and education sector (Kusińska, 2014, p. 64-127). The purpose of this article is to verify projects implemented in this area, which were qualified for co-financing from structural funds in the years 2004-2006. The object of the research covered 2,947 investments implemented in 16 provinces. ${ }^{1}$ The selection of the sample was not accidental, it was deliberately limited to one priority subject - science and education. The period of study was also planned for the years 2004-2006 (Ministerstwo..., 2013), so the first financial perspective in which Poland had already participated as a member of the European Union (Sikora-Gaca, Piechowicz, Kleinowski, 2016).

The article distinguishes projects financed from specific structural funds. The participation of the European Regional Development Fund, the European Social Fund and the European Agricultural Guidance and Guarantee Fund in the projects in the area of

${ }^{1}$ In the following financial perspective - in years 2007-2013 - 22,341 projects were contracted for implementation, which will be subjected to further analysis. 
science and education in Poland in 2004-2006 was verified. ${ }^{2}$ The number of projects, the total value of projects and the value of obtained subsidies by Universities and Universities of Technology have been specified, as well as data on 2,947 projects, broken down by individual provinces. Thanks to this, regional leaders were distinguished in terms of the number of complex projects or financial resources obtained, and the matrix of data was presented by means of charts, figures and tables. The average percentage of cofinancing for projects in the area of science and education, the average percentage share of subsidies from structural funds in implemented investments, and the average value of subsidies for one project have also been specified. Such separate analyzes also allowed to calculate the value of EU subsidies for projects in the area of science and education in Poland, in the years 2004-2006 per one inhabitant in individual provinces.

The study also analyzed selected indicators of human capital development for the years 2003, 2006, 2009 and 2012 (their selection will be justified in the further part of the study), both those referring to Poland in general and in a regional cross-section including 16 provinces.

The study applied a quantitative research method using the structure and dynamics indicators. Numerical data was obtained from the database serviced by the Ministry of Development (Mapa), and in the case of human capital indicators - from the Central Statistical Office.

\section{Share of structural funds in projects from the area of science and education implemented in 2004-2006}

In the years 2004-2006 in Poland, 2,947 projects were implemented in the field of science and education. They were co-financed from three structural funds: the European Regional Development Fund (ERDF), the European Social Fund (ESF) and the European Agricultural Guidance and Guarantee Fund (EAGGF). The value of 2,947 projects in total amounted to approx. 5.75 billion zk, of which the amount of co-financing from the EU for completed projects amounted to 3.94 billion zł. In 2006, the amount of EU subsidies for projects in the area of science and education per one inhabitant of Poland amounted to $103.35 \mathrm{zl}$ (Rządowa..., 2007, p. 9). In 2004-2006, the departments of the Ministry of National Education were beneficiaries in 53 projects, the total value of which amounted to 2.25 billion zł. These projects were financed in over $70 \%$ ( 1.67 billion zł) by the EU. In the analyzed period, the Universities implemented 65 investments, the total value of which amounted to 412.97 million $\mathrm{z}$, including the value of co-financing from the EU - 272.62 million zł. Universities of Technology completed 25 projects less -40 . Their total value amounted to 191.91 million zt, including the value of EU subsidies of 105.33 million zł. This detailed data is presented in Chart 1.

With the participation of the European Regional Development Fund, 1,950 projects were implemented. Their total value amounted to 1.71 billion $\mathrm{zl}$, of which EU funding

${ }^{2}$ It should be added that in the years 2004-2006 applicants could submit applications until 31.12.2006 with the implementation period until 31.12.2009. This means that the duration of each financial perspective is the time in which funds are contracted to be spent, and their implementation is much longer than the timeframe of the EU budget. 
amounted to over $64 \%-1.1$ billion zł. The share of the state budget in completed investments amounted to approximately 0.19 billion $\mathrm{zl}$, and the beneficiaries' own contribution amounted to 0.38 billion $\mathrm{zl}^{3}{ }^{3} \mathrm{Co}$-financing was granted as part of the Integrated Regional Operational Program, as part of two measures: 1.3 - Regional social infrastructure and 2.2 - Equalizing educational opportunities through scholarship programs. Most of all, infrastructure projects, various types of modernization, construction, reconstruction or extension works were carried out. A wide range of investments also included scholarship programs aimed at broadly understood equal opportunities for primary, secondary and university students at various levels of education. The greatest value was achieved by three projects: "Science and Music Education Center SYMFONIA," "Construction of a new building for the Faculty of Electronics, Telecommunications and Informatics of the Gdansk University of Technology" and "Construction of the Didactic and Scientific Center of Modern Languages at the University of Silesia in Sosnowiec." For 1,950 completed projects, the total value of two exceeded 40 million zł, also of other two - 30 million $\mathrm{zl}$, and of five - 20 million $\mathrm{zl}$.

\section{Chart 1. Number of projects in the area of science and education, total value of projects and the value of obtained subsidies by Universities and Universities of Technology in Poland in 2004-2006}

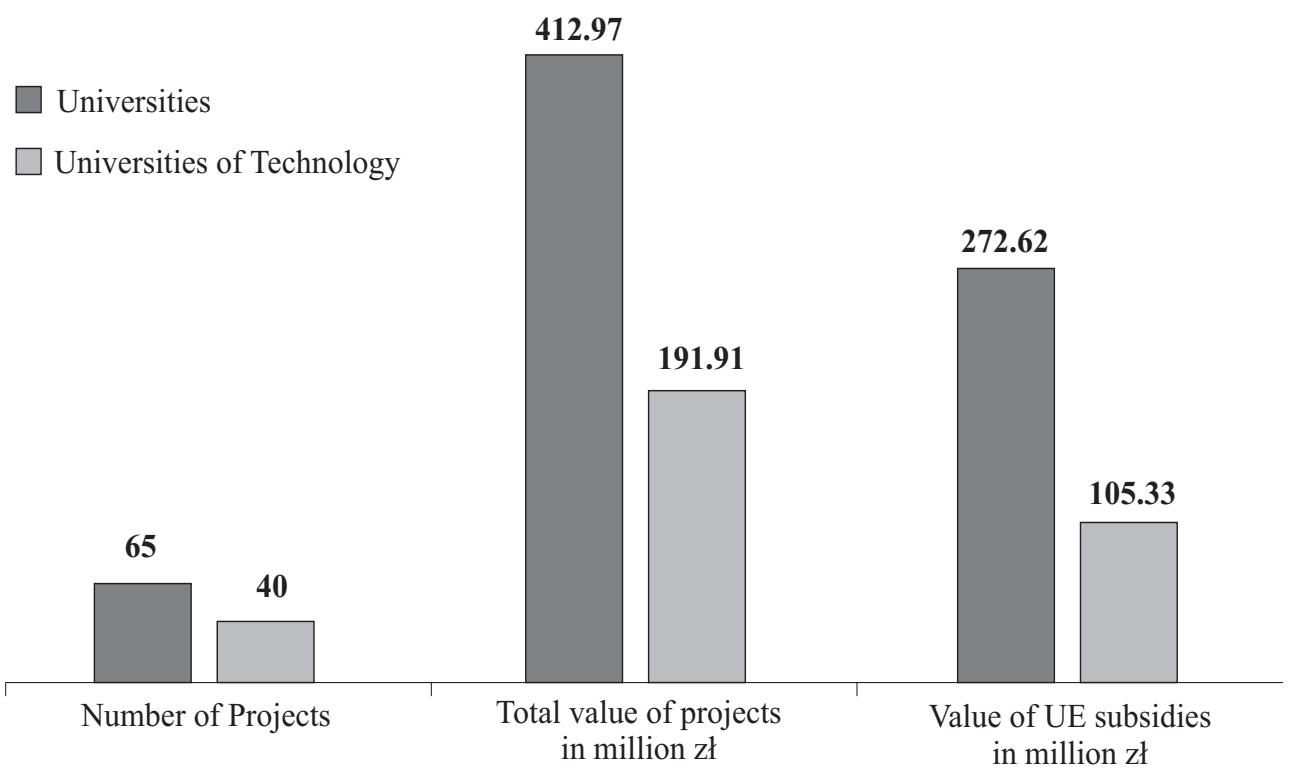

Source: Own study, based on (Mapa).

${ }^{3}$ Assuming that the average own contribution of the beneficiary was $30 \%$.

${ }^{4}$ Beneficiary - Academy of Music in Katowice, total value of the project - 57.22 million zł, value of EU funding - 29.28 million zł.

${ }^{5}$ Beneficiary - Gdańsk University of Technology, total project value -53.44 million zł, EU subsidy -12.27 million zł.

${ }^{6}$ Beneficiary - a consortium of the Sosnowiec municipality and the University of Silesia, the total value of the project - 52.04 million zł, the value of EU subsidies - 36.11 million $\mathrm{zl}$. 
815 projects were implemented with the participation of the European Social Fund. Applications were submitted as part of the Human Resources Development Operational Program, measure 2.2 - Improving the quality of education in relation to the needs of the labor market and measure 2.1 - Increasing access to education, promotion of lifelong learning. The total value of 815 projects amounted to 3.96 billion $\mathrm{z}$, including the value of the obtained EU subsidies -2.77 billion zł. The state budget contribution to completed investments amounted to approx. 0.48 billion zł. The largest beneficiary of the assistance from the ESF was the Department of Improving Educational Opportunities in the Ministry of National Education, which for the implementation of the project "Computer rooms for schools" received 855.61 million $\mathrm{zl}$ from EU subsidies. The value of the entire project amounted to 1.14 billion zł. These were the undertakings implemented by the Department of General and Specialist Education of the Ministry of National Education, the Department of Improving Educational Opportunities in the Ministry of National Education and the Foundation of the Regional Agency for the Promotion of Employment. The above-mentioned MNE departments carried out three more projects, the total value of which exceeded the amount of 90 million zł.

The last structural fund which in the years 2004-2006 supported projects in the area of science and education was the European Agricultural Guidance and Guarantee Fund. It co-financed 182 investments. The projects were implemented as part of the restructuring and modernization of the food sector program and development of rural resources (primarily measure 1.3 - Training). Total value of projects amounted to 73.52 million $\mathrm{zl}$, of which the value of EU subsidies accounted for almost $80 \%-60$ million zł. The state budget added approximately $10.37 \mathrm{zł}$ million to the aforementioned investments.

Chart 2. Number of projects in the area of science and education, co-financed by individual structural funds in Poland in 2004-2006

1950

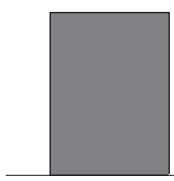

815

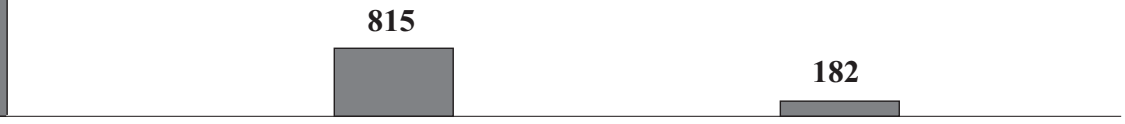

ERDF

ESF

EAGGF

Source: Own study, based on (Mapa).

By far the largest range of investments in the field of science and education in 20042006 in terms of the number of projects was implemented with the participation of the European Regional Development Fund, while the largest amount of funds was implemented from the European Social Fund.

\section{Share of individual provinces in projects in the area of science and education implemented in 2004-2006}

This article already specifies the number of projects in the area of science and education co-financed from the EU funds, implemented in Poland in the years 2004-2006 with 
the participation of individual structural funds. The amount of subsidies in the area of science and education per capita in Poland in $2006-103.35 \mathrm{zl}$, was also calculated. At the further stage of the research, it was decided to determine how the results presented earlier worked in individual provinces. Detailed data are presented in Figures 1, 2 and 3.

A clear leader in terms of the number of projects approved for implementation, in the years 2004-2006 was the Masovian province - 394 investments. Over 300 investments were implemented by two provinces: Silesian and Greater Poland. In the Pomeranian province, 211 projects in the field of science and education were carried out in 2004-2006, while in the West Pomeranian - 201. Over 100 projects were contracted for implementation in eight provinces, of which only three were over 150. In the Opole province, co-financing was obtained for 97 of analyzed investments. The smallest number of projects was contracted for implementation in the Świętokrzyskie province -68 and in the Kuyavian-Pomeranian - 61. Of course, the number of completed projects does not translate into the total value of projects or the value of the co-financing obtained.

Figure 1. Number of projects in the area of science and education, co-financed by the EU, implemented in individual provinces in 2004-2006

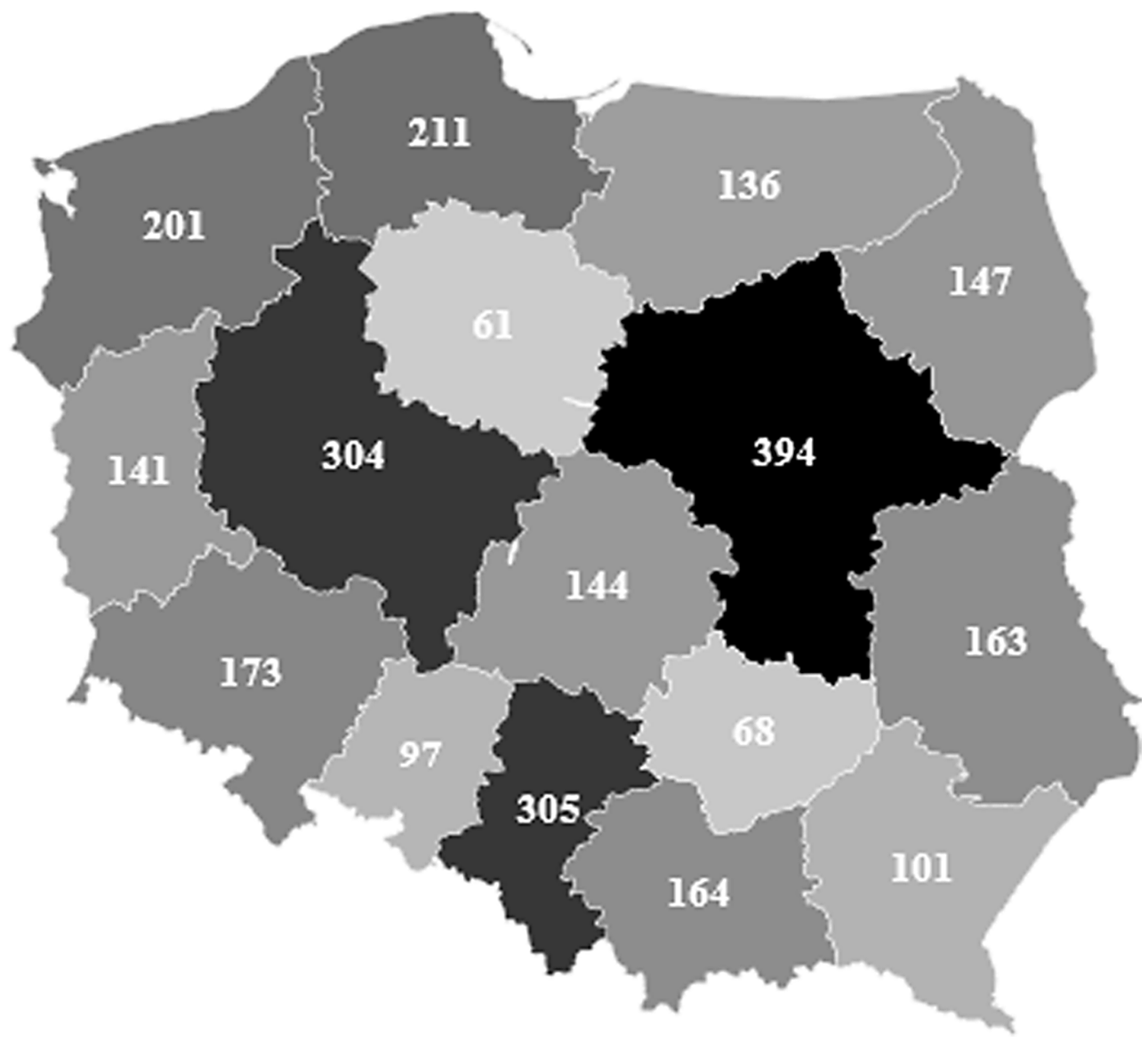

Source: Own study, based on (Mapa). 
Figure 2. Total value of projects from the area of science and education co-financed by the EU, implemented in individual provinces in 2004-2006, in million zl

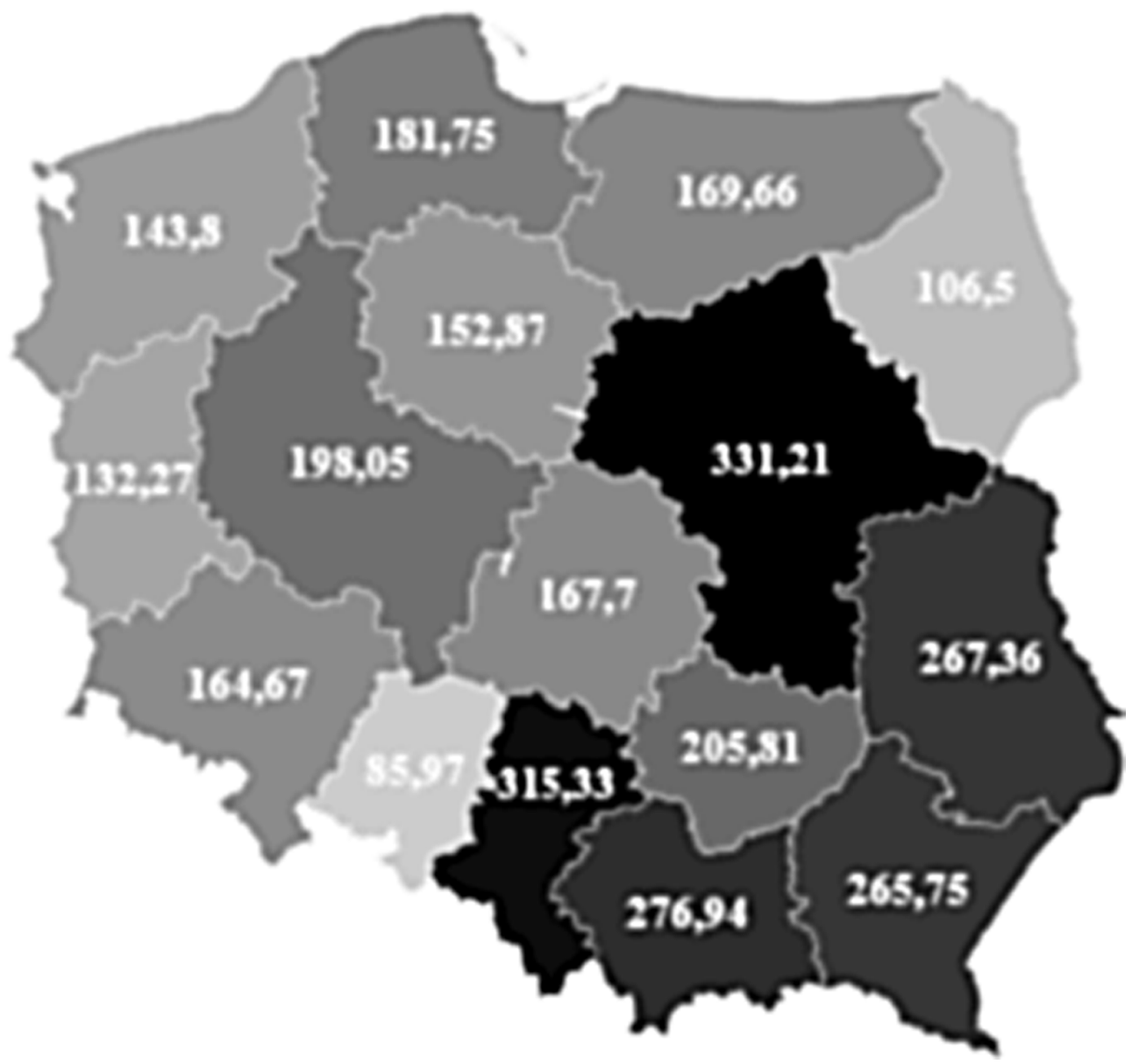

Source: Own study, based on (Mapa).

The highest total value of projects in the area of science and education in the years 2004-2006 was achieved by investments realized in the Mazovian and Silesian provinces -331.21 million $\mathrm{z}$ and 315.33 million $\mathrm{z}$, respectively. In four provinces, the total investment value was over 200 million zł. These were: Świętokrzyskie, Podkarpackie, Lesser Poland and Lublin. In these regions, the total investment value was, respectively: 205.81 (for 68 projects), 256.75 (101), 276.94 (164) and 267.36 (163) million zł. This confirms the rule that the number of completed investments does not affect their value and the amount of co-financing received. The lowest total value was achieved by projects implemented in the Opole province ( 85.97 million zł). In other regions, the total value of projects in the area of science and education, contracted for implementation in 2004-2006, exceeded 100 million zł.

When analyzing the number of educational projects implemented with the participation of structural funds in individual provinces and their total value, it is also necessary 
Figure 3. Value of EU subsidies for projects in the area of science and education implemented in individual provinces in 2004-2006, in million zl

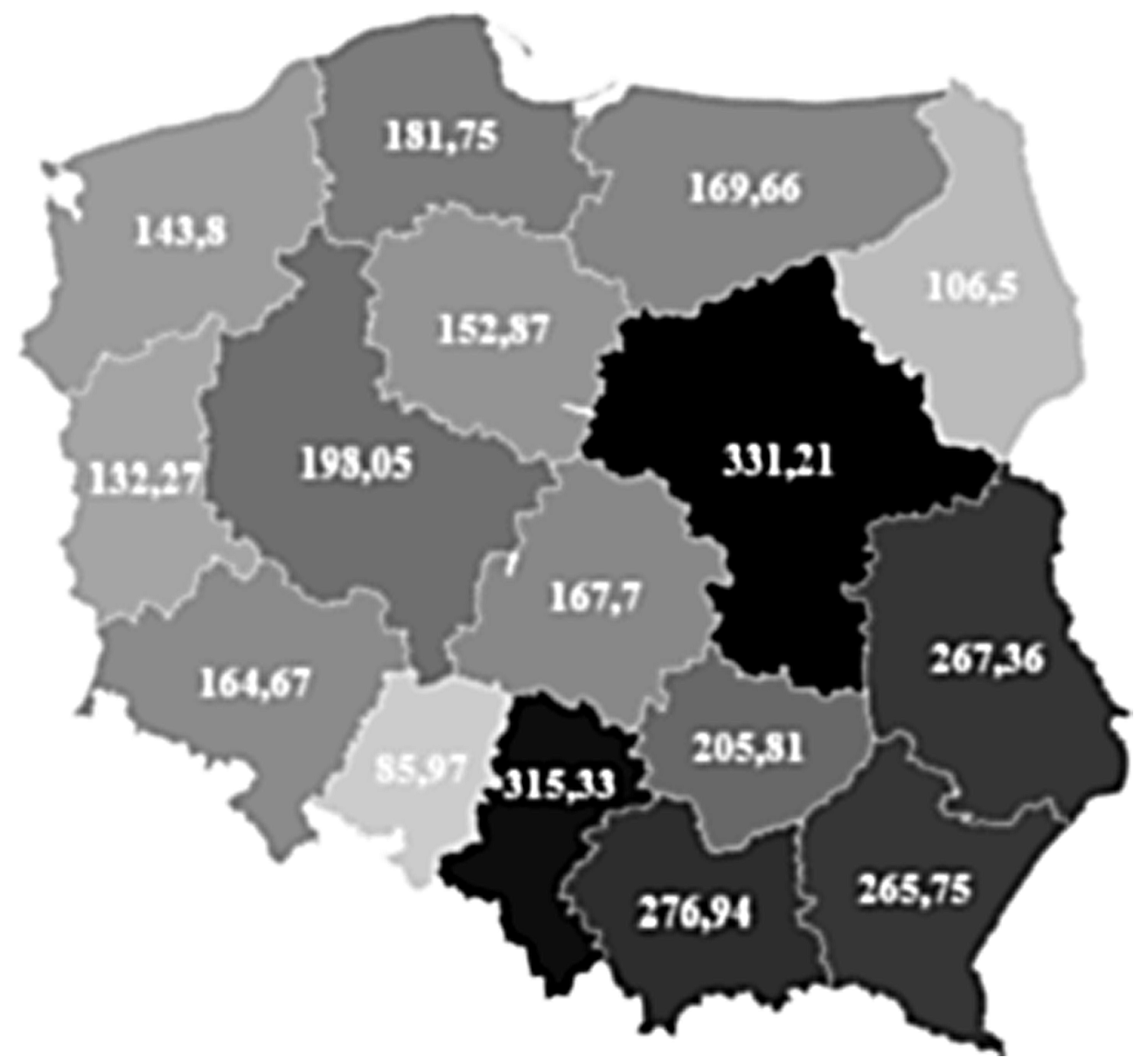

Source: Own study, based on (Mapa).

to verify the amounts of the co-financing received. They are independent of the first two factors mentioned and can be varied. Detailed data on the value of obtained subsidies is presented in Figure 3.

An analysis of the percentage share of the value of co-financing obtained in relation to the total value of projects was also made. Based on the calculations performed, it was determined that the lowest average percentage of co-financing for projects in the area of science and education in 2004-2006 was achieved in the Pomeranian province $-53.11 \%$, and the highest in the Kuyavian-Pomeranian $-68.97 \% .^{7}$ The average percentage share of

${ }^{7}$ The percentage share of subsidies from structural funds, in projects in the area of science and education, contracted for implementation in 2004-2006, in individual provinces was as follows: West Pomeranian - 66.44\%, Greater Poland - 67.67\%, Warmian-Masurian - 67.18\%, Świętokrzyskie $-67.50 \%$, Silesian $-64.12 \%$, Pomeranian $-53.11 \%$, Podlasie $-69.25 \%$, Podkarpackie $-68.31 \%$, 
subsidies from structural funds in projects in the area of science and education contracted for implementation in 2004-2006 amounted to $65.52 \%$. The highest value of subsidies from structural funds for one project implemented in the area of science and education, in 2004-2006, was achieved in the Świętokrzyskie province - 2.04 million zł, while the lowest in Greater Poland -0.44 million zł. The average value of subsidies for one project amounted to 0.87 million zt. ${ }^{8}$

\section{Subsidies per capita for projects in the area of science and education implemented in 2004-2006 in individual provinces}

For the purpose of this article, the value of subsidies per one inhabitant of each province (chart 3$)^{9}$ was also calculated for projects in the area of science and education, contracted in 2004-2006. These data were compared with the previously discussed number of total projects implemented in 16 Polish provinces, the value of subsidies to projects in total in million $\mathrm{zl}$, and the value of subsidies for one project in the province, as presented in Table $1 .{ }^{10}$

Interestingly, in terms of the value of subsidies per capita, for projects in the area of science and education in 2004-2006, the best result was achieved in the Świętokrzyskie province $-109.39 \mathrm{zk}$, which in terms of the number of projects contracted for implementation was at the 15th place, and in terms of the value of subsidies obtained for projects in total at the 6th place. The second largest value of subsidies per one inhabitant was achieved in the Lubusz province $-88.98 \mathrm{zl}$ (11th in terms of the number of projects contracted for implementation, 14th place in terms of the value of subsidies obtained for total projects). The third - in the Podkarpackie province $-83.92 \mathrm{zl}$ (13th and 4th place respectively). The fourth - Warmian-Masurian -80.26 (respectively 12 th and 8 th place),

Opole $-67.74 \%$, Mazovian - 65.12\%, Lesser Poland - 65.65\%, Łódź - 65.05\%, Lubusz - 67.27\%, Lublin $-60.28 \%$, Kuyavian-Pomeranian $-68.97 \%$, Lower Silesia $-64.70 \%$.

${ }^{8}$ Average value of subsidies from structural funds for one project in the area of science and education in 2004-2006, in individual provinces (in zł) of: West Pomeranian - 0.47 million, Greater Poland - 0.44 million, Warmian-Masurian - 0.83 million, Świętokrzyskie - 2.04 million, Silesia - 0.66 million, Pomeranian -0.45 million, Podlasie -0.50 million, Podkarpackie -1.73 million, Opole - 0.60 million, Mazovia -0.54 million, Lesser Poland - 1.10 million, Łódź -0.75 million, Lubusz - 0.63 million, Lublin - 0.98 million, Kuyavian-Pomeranian - 1.72 million, Lower Silesia -0.61 million.

9 See: Governmental Population Council of Poland, Sytuacja demograficzna Polski. Raport 2006-2007, Warsaw 2007. On the basis of the source, the following number of population for each province was assumed in 2006 in million people: West Pomeranian - 1.69, Greater Poland - 3.37, Warmian-Masurian - 1.42, Świętokrzyskie - 1.27, Silesia - 4.66, Pomeranian - 2.2, Podlasie - 1.19, Podkarpackie - 2.09, Opole - 1.04, Mazovian - 5.17, Lesser Poland - 3.27, Łódź - 2.56, Lubusz - 1, Lublin - 2.17, Kuyavian-Pomeranian - 2.06, Lower Silesia - 2.88 .

${ }^{10}$ Data on the project's total value per capita in 2006, in the area of science and education were not used in the analyzes, however, due to the possibility of their practical use in further research, it was decided to include it in this article (in zł): West Pomeranian - 85.08, Greater Poland - 58.76, WarmianMasurian - 119.47, Świętokrzyskie - 162.05, Silesian - 67.66, Pomeranian - 82.61, Podlasie - 89.49, Podkarpackie - 122.84, Opole - 82.66, Mazovian - 64.06, Lesser Poland - 84.69, Łódź - 65.5, Lubusz - 132.27, Lublin - 123.20, Kuyavian-Pomeranian - 74.20, Lower Silesia - 57.17. 
and the fifth - Lublin - $74.27 \mathrm{zl}$ (respectively 8 th and 5th place). The analysis shows that, in the analyzed period in the provinces of Eastern Poland, the largest amount of support from structural funds per capita was implemented in the area of science and education.

Chart 3. Value of subsidies from the EU per one inhabitant of the province to the project in the area of science and education, in 2006 , in $\mathrm{zl}$

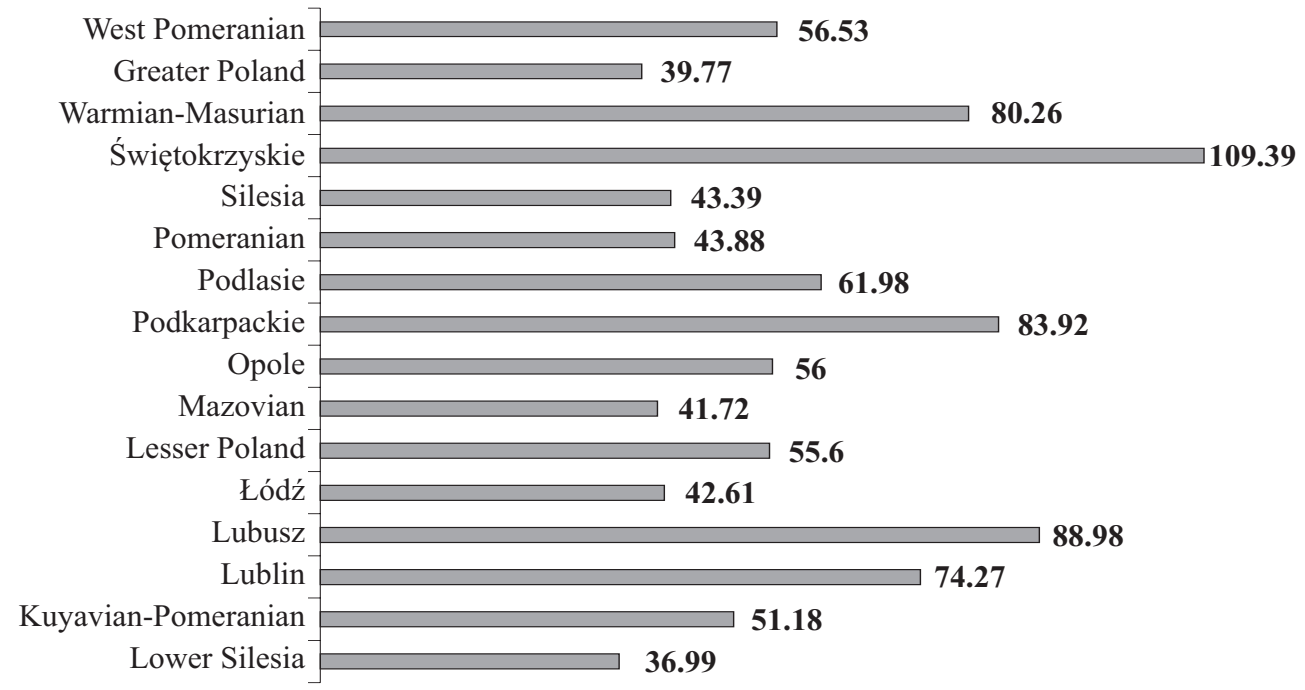

Source: Own study, based on (Mapa).

Table 1

Ranking of Polish provinces in terms of implementation of projects in the area of science and education, co-financed from structural funds, in 2004-2006

\begin{tabular}{|c|c|c|c|c|c|c|}
\hline \multirow[t]{2}{*}{ Province } & \multicolumn{2}{|c|}{$\begin{array}{l}\text { Value of subsidies } \\
\text { per capita in } 2006\end{array}$} & \multicolumn{2}{|c|}{$\begin{array}{c}\text { Number of projects con- } \\
\text { tracted for implementation } \\
\text { in 2004-2006 }\end{array}$} & \multicolumn{2}{|c|}{$\begin{array}{c}\text { Value of subsidies for projects } \\
\text { contracted for implementation } \\
\text { in provinces in } 2004-2006\end{array}$} \\
\hline & \begin{tabular}{|c|} 
indicator \\
value in $\mathrm{zl}$
\end{tabular} & place & $\begin{array}{c}\text { indicator value } \\
\text { in project number }\end{array}$ & place & $\begin{array}{c}\text { indicator value in } \\
\mathrm{mln} \mathbf{z l}\end{array}$ & place \\
\hline West Pomeranian & 56.53 & 7 & 201 & 5 & 95.55 & 13 \\
\hline Greater Poland & 39.77 & 15 & 304 & 3 & 134.04 & 7 \\
\hline Warmian-Masurian & 80.26 & 4 & 136 & 12 & 113.98 & 8 \\
\hline Świętokrzyskie & 109.39 & 1 & 68 & 15 & 138.93 & 6 \\
\hline Silesian & 43.39 & 12 & 305 & 2 & 202.21 & 2 \\
\hline Pomeranian & 43.88 & 11 & 211 & 4 & 96.54 & 12 \\
\hline Podlasie & 61.98 & 6 & 147 & 9 & 73.76 & 15 \\
\hline Podkarpackie & 83.92 & 3 & 101 & 13 & 175.41 & 4 \\
\hline Opole & 56.00 & 8 & 97 & 14 & 58.24 & 16 \\
\hline Mazovian & 41.72 & 14 & 394 & 1 & 215.7 & 1 \\
\hline Lesser Poland & 55.60 & 9 & 164 & 7 & 181.82 & 3 \\
\hline Łódź & 52.61 & 13 & 144 & 10 & 109.09 & 9 \\
\hline Lubusz & 88.98 & 2 & 141 & 11 & 88.98 & 14 \\
\hline Lublin & 74.27 & 5 & 163 & 8 & 161.18 & 5 \\
\hline Kuyavian-Pomeranian & 51.18 & 10 & 61 & 16 & 105.44 & 11 \\
\hline Lower Silesian & 36.99 & 16 & 173 & 6 & 106.55 & 10 \\
\hline
\end{tabular}

Source: Own study. 
The Mazovian province, leading in previous analyzes in terms of the value of subsidies per capita, for projects in the area of science and education in 2004-2006 obtained only the 14th result $-41.72 \mathrm{zl}$ (first in terms of the number of projects contracted for implementation, first place in terms of the value of subsidies obtained for projects in total). Similar was the case of the Silesian and Greater Poland provinces. In terms of the value of subsidies per capita, the Silesian province reached the value of $43.39 \mathrm{zl}$ - the 12th place (second in terms of the number of projects contracted for implementation, second place in terms of the value of subsidies obtained for projects in total). In terms of the value of subsidies per capita, Greater Poland reached $39.77 \mathrm{zl}-15$ th (third place in terms of the number of projects contracted for implementation, 7 th place in terms of the value of subsidies obtained for projects in total).

\section{Development of human capital in Poland and structural funds in the area of science and education}

European financial support for the Polish education and science has been going on for over a decade. It is worth looking at and assessing its effectiveness from the point of view of its impact on the development of human capital in Poland.

The category of human capital, equivalent in terms of the importance of other growth factors (such as capital, labor, technology), appeared in the considerations of economists in the 1960s, along with the spread of the term "knowledge-based economy" (Czajkowski, 2012, p. 4). It is defined, among others, as a "resource of knowledge and skills, health and vital energy contained in a given society" (Domański, 1993, p. 19). In this broad approach, this category will consist of three basic components: intellectual, social and emotional capital, i.e. knowledge, skills, professional experience on the one hand, and relationships, trust and interpersonal relationships on the other, complemented by aspirations, standards, values and behavioral patterns (Król, Ludwiczyński, 2006, p. 118-119).

Most of the abovementioned skills forming human capital are acquired in the process of broadly understood education, starting from the nursery and pre-school education, to the lifelong learning implemented in adulthood. Hence, among the many indicators of human capital, ${ }^{11}$ those relating to the sphere of education are of much importance.

In this study, for the purpose of assessing changes in the level of human capital in Poland (including regional differences), in the context of the use of European funds for projects in the area of science and education, the following indicators were adopted:

- population structure by level of education;

- percentage of children aged 3-5 covered by pre-school education (in Poland, in individual provinces, broken down by city / village);

- students per 1 computer with Internet access to be used by students (primary and lower secondary/junior high schools, divided into provinces);

${ }^{11}$ These include demographic indicators (number and age structure of population), indicators referring to the health status of the population (average age, access to health care, mortality) or the labor market (average salary, unemployment rate, employment and professional activity rates) (Miciuła, Miciuła, 2015, p. 9; Więziak-Białowolska, 2011, p. 43-44). 
- results of Polish students in PISA tests (mathematics, natural sciences) in comparison to the European Union countries;

- percentage of people aged 25-64 participating in lifelong learning in individual provinces.

For the majority of the data presented above, the following years were taken into analysis: 2003 (before the accession to the European Union), 2006 (the end of the first financial perspective) and 2009 and 2012 (to track changes taking place in the education sector). In case of the absence of data for the above-mentioned years, the following years were taken into consideration.

Chart 4. Structure of Polish population aged between 25 and 59 by education level in 2001, 2006, 2009 and 2012

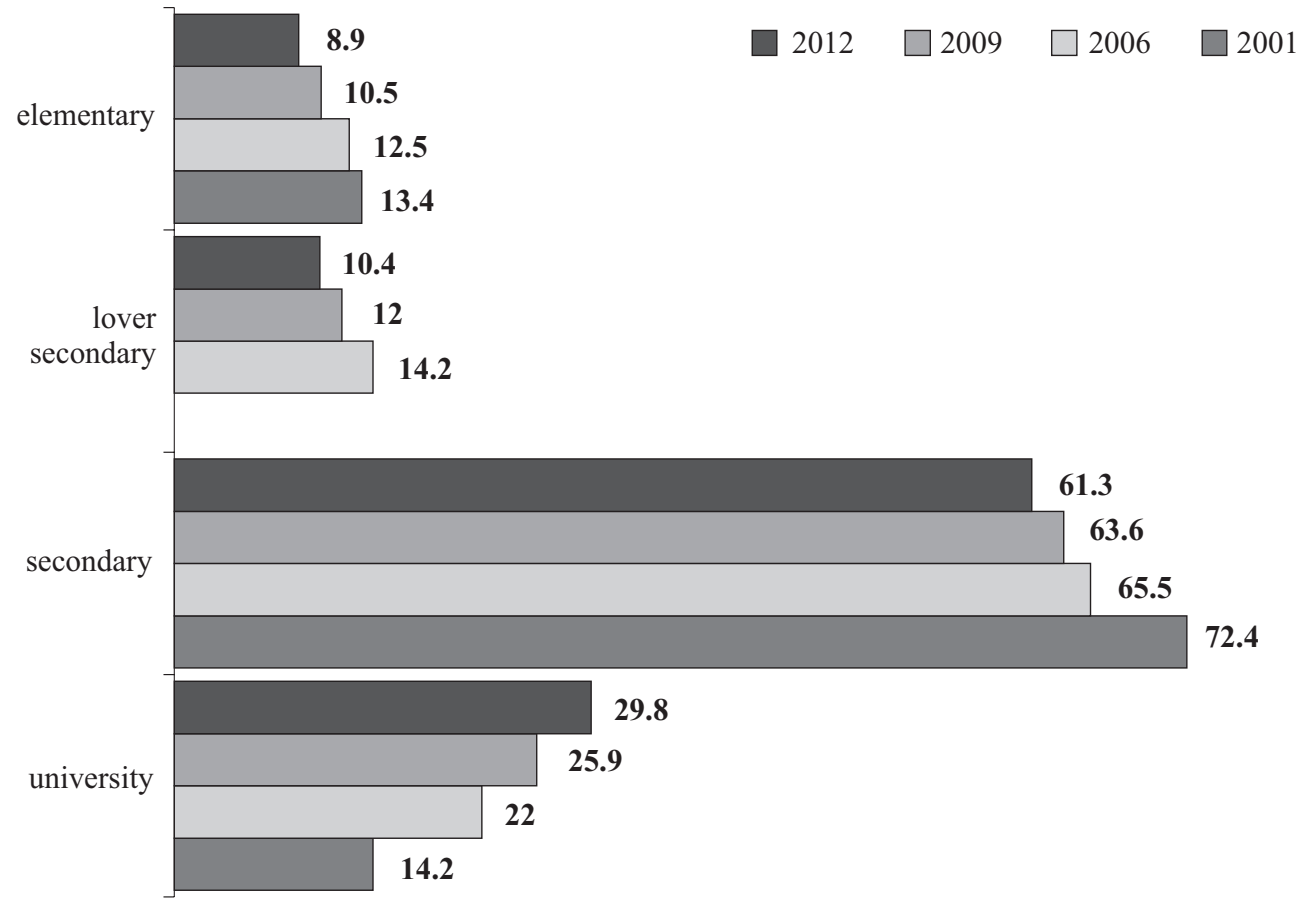

Source: Own study, based on: Sprawozdanie, 2013, p. 12.

Over the analyzed years, the share of people with higher education has risen dramatically (more than twice). At the same time, the shares of people with the lowest education, i.e. primary and lower secondary education, dropped quite significantly. These two positive tendencies testify to the increase in the level of education in the Polish society.

The access to pre-school education is one of the indicators used in the measure of quality of life in a given country. Cheap and widely available education for children is not only one of the determinants of faster return of women to the labor market, but also the best form of fighting inequalities in the area of education, in rural areas in particular. 
Percentage of children aged 3-5 participating in pre-school education

\begin{tabular}{|c|c|c|c|c|c|c|c|}
\hline \multirow{2}{*}{ Province } & \multicolumn{4}{|c|}{ Overall } & \multirow{2}{*}{$\begin{array}{l}\text { Ranking } \\
\text { in } 2003\end{array}$} & \multirow{2}{*}{$\begin{array}{l}\text { Ranking } \\
\text { in } 2012\end{array}$} & \multirow{2}{*}{$\begin{array}{c}\text { Dynamics indicator } \\
(\text { year } 2003=100)\end{array}$} \\
\hline & 2003 & 2006 & 2009 & 2012 & & & \\
\hline Poland & 38.0 & 44.6 & 59.7 & 69.7 & - & - & 183.4 \\
\hline Lower Silesian & 39.0 & 46.3 & 61.3 & 70.2 & 7 & 6 & 180.0 \\
\hline Kuyavian-Pomeranian & 30.0 & 34.0 & 49.2 & 61.7 & 13 & 15 & 205.7 \\
\hline Lublin & 31.8 & 35.7 & 52.5 & 65.7 & 11 & 12 & 206.6 \\
\hline Lubusz & 40.6 & 47.1 & 60.5 & 68.1 & 5 & 8 & 167.7 \\
\hline Łódź & 40.0 & 46.1 & 60.8 & 70.9 & 6 & 5 & 177.25 \\
\hline Lesser Poland & 37.1 & 43.6 & 58.7 & 69.8 & 8 & 7 & 188.1 \\
\hline Mazovian & 40.7 & 49.4 & 65.5 & 75.6 & 4 & 2 & 185.7 \\
\hline Opole & 56.4 & 64.5 & 76.8 & 77.9 & 1 & 1 & 138.1 \\
\hline Podkarpackie & 31.4 & 35.5 & 51.3 & 63.8 & 12 & 14 & 203.2 \\
\hline Podlasie & 29.2 & 36.9 & 54.4 & 67.2 & 14 & 9 & 230.1 \\
\hline Pomeranian & 31.9 & 37.9 & 54.1 & 66.1 & 10 & 10 & 207.2 \\
\hline Silesian & 48.3 & 56.1 & 68.5 & 74.4 & 2 & 3 & 154.0 \\
\hline Świętokrzyskie & 28.7 & 33.9 & 51.1 & 64.3 & 15 & 13 & 224.0 \\
\hline Warmian-Masurian & 28.0 & 34.1 & 47.7 & 60.4 & 16 & 16 & 215.7 \\
\hline Greater Poland & 45.5 & 51.9 & 65.8 & 73.7 & 3 & 4 & 162.0 \\
\hline West Pomeranian & 32.9 & 39.9 & 56.2 & 65.9 & 9 & 11 & 200.3 \\
\hline \multicolumn{8}{|c|}{ Rural areas } \\
\hline Poland & 20.3 & 21.4 & 37.5 & 50.8 & - & - & 250.2 \\
\hline Lower Silesian & 17.6 & 17.9 & 34.9 & 45.9 & 8 & 12 & 260.8 \\
\hline Kuyavian-Pomeranian & 13.4 & 12.7 & 27.3 & 42.3 & 13 & 13 & 315.7 \\
\hline Lublin & 16.2 & 14.7 & 31.3 & 48.9 & 10.5 & 10 & 301.8 \\
\hline Lubusz & 21.9 & 22.7 & 35.1 & 46.0 & 6 & 11 & 210.0 \\
\hline Łódź & 21.8 & 21.0 & 38.0 & 51.7 & 7 & 6 & 237.1 \\
\hline Lesser Poland & 22.0 & 25.6 & 41.9 & 55.9 & 5 & 3 & 254.1 \\
\hline Mazovian & 16.2 & 18.7 & 37.0 & 51.8 & 10.5 & 5 & 319.7 \\
\hline Opole & 50.3 & 52.8 & 63.1 & 65.7 & 2 & 2 & 130.6 \\
\hline Podkarpackie & 17.9 & 18.8 & 35.4 & 50.2 & 7 & 8.5 & 280.4 \\
\hline Podlasie & 8.5 & 7.7 & 21.7 & 40.5 & 16 & 14 & 476.5 \\
\hline Pomeranian & 14.3 & 16.9 & 34.7 & 50.2 & 12 & 8.5 & 351.0 \\
\hline Silesian & 37.1 & 43.3 & 61.5 & 67.2 & 3 & 1 & 181.1 \\
\hline Świętokrzyskie & 16.6 & 15.5 & 33.7 & 50.7 & 9 & 7 & 305.4 \\
\hline Warmian-Masurian & 9.6 & 10.3 & 21.2 & 36.7 & 14 & 15 & 382.3 \\
\hline Greater Poland & 30.7 & 30.8 & 44.2 & 53.7 & 4 & 4 & 174.9 \\
\hline West Pomeranian & 9.1 & 8.2 & 24.8 & 35.9 & 15 & 16 & 394.5 \\
\hline
\end{tabular}

Source: Own study, based on: Central Statistical Office (GUS), (Bank).

As can be seen from the data contained in Table 2, both in Poland and in all provinces, there has been a radical increase in the access to pre-school education expressed in the increasing percentage of children covered by this education. The provinces in which this percentage was the highest in 2012 were: Opole, Mazovian, Silesian and Greater Poland. On the other hand, provinces in which the situation in this area improved the most in relation to 2003 were: Podlasie, Świętokrzyskie and Warmian-Masurian. What is especially important, during the considered period the availability of kindergartens for children from rural areas has significantly increased. More than a threefold increase in 
the percentage of children attending kindergartens took place in the following provinces: West Pomeranian, Warmian-Masurian, Pomeranian, Mazovian, Kuyavian-Pomeranian, Świętokrzyskie and Lublin. In the Podlasie province, the increase was more than a fourfold. After compiling this data with the ranking of provinces in terms of the value of subsidies per capita (Table 1), it turns out that provinces, in which the access to pre-school education improved the most, at the same time obtained high positions in this ranking.

The increase in the number of educational institutions (including kindergartens) is the first step on the road to improving the level of human capital in a given country. The next is to equip them with modern IT infrastructure, including the Internet access.

Table 3

Students per 1 computer with Internet access in 2003, 2006, 2009, 2012

\begin{tabular}{|c|c|c|c|c|c|c|c|}
\hline Province & 2003 & 2006 & 2009 & 2012 & $\begin{array}{l}\text { Ranking } \\
\text { in } 2003\end{array}$ & $\begin{array}{l}\text { Ranking } \\
\text { in } 2012\end{array}$ & $\begin{array}{c}\text { Dynamics indicator } \\
(\text { year } 2003=100)\end{array}$ \\
\hline \multicolumn{8}{|c|}{ Primary schools } \\
\hline Poland & 42.79 & 17.75 & 11.62 & 10.02 & - & - & 76.6 \\
\hline Lower Silesian & 41.43 & 18.49 & 11.92 & 9.78 & 7 & 6 & 76.4 \\
\hline Kuyavain-Pomeranian & 47.01 & 19.01 & 12.38 & 11.03 & 12 & 13 & 76.5 \\
\hline Lulin & 37.05 & 14.25 & 9.05 & 8.06 & 2 & 3 & 78.3 \\
\hline Lubusz & 49.00 & 19.91 & 12.30 & 10.87 & 14 & 12 & 77.8 \\
\hline Łódź & 43.44 & 17.88 & 10.91 & 9.89 & 9 & 8 & 77.2 \\
\hline Lesser Poland & 39.17 & 15.89 & 10.86 & 9.22 & 4 & 5 & 76.5 \\
\hline Mazovian & 42.36 & 17.68 & 12.25 & 10.86 & 8 & 11 & 74.4 \\
\hline Opole & 40.35 & 15.98 & 9.72 & 7.85 & 5 & 2 & 80.6 \\
\hline Podkarpackie & 35.58 & 14.11 & 8.53 & 7.55 & 1 & 1 & 78.8 \\
\hline Podlasie & 37.61 & 17.48 & 11.78 & 10.10 & 3 & 9 & 73.2 \\
\hline Pomeranian & 46.14 & 20.74 & 14.01 & 12.50 & 11 & 16 & 72.9 \\
\hline Silesian & 52.11 & 21.52 & 14.86 & 12.19 & 16 & 15 & 76.6 \\
\hline Świętokrzyskie & 50.48 & 16.50 & 10.17 & 8.33 & 15 & 4 & 83.5 \\
\hline Warmian-Masurian & 48.04 & 19.21 & 12.20 & 9.84 & 13 & 7 & 79.5 \\
\hline Greater Poland & 40.25 & 17.81 & 12.15 & 10.21 & 6 & 10 & 74.6 \\
\hline West Pomeranian & 45.24 & 20.70 & 12.73 & 11.15 & 10 & 14 & 75.4 \\
\hline \multicolumn{8}{|c|}{ Secondary schools } \\
\hline Poland & 27.82 & 18.21 & 12.23 & 10.17 & - & - & 63.5 \\
\hline Lower Silesian & 29.10 & 17.78 & 12.09 & 9.33 & 10 & 4 & 68.0 \\
\hline Kuyavian-Pomeranian & 32.07 & 21.54 & 13.57 & 11.46 & 16 & 14 & 64.3 \\
\hline Lublin & 28.78 & 17.34 & 10.46 & 9.29 & 9 & 3 & 67.7 \\
\hline Lubusz & 31.30 & 19.45 & 14.32 & 12.07 & 13 & 16 & 61.4 \\
\hline Łódź & 28.30 & 19.41 & 12.55 & 10.39 & 5 & 9.5 & 63.3 \\
\hline Lesser Poland & 26.06 & 17.06 & 11.93 & 10.18 & 3 & 7 & 60.9 \\
\hline Mazovian & 24.30 & 16.12 & 11.64 & 10.16 & 2 & 5.5 & 51.9 \\
\hline Opole & 28.48 & 17.78 & 11.93 & 6.76 & 6 & 1 & 76.3 \\
\hline Podkarpackie & 23.17 & 15.70 & 9.91 & 8.66 & 1 & 2 & 62.6 \\
\hline Podlasie & 28.59 & 19.26 & 12.38 & 10.53 & 7 & 11 & 63.2 \\
\hline Pomeranian & 31.56 & 20.35 & 13.62 & 11.53 & 14 & 15 & 63.5 \\
\hline Silesian & 28.62 & 18.57 & 13.07 & 11.12 & 8 & 13 & 61.2 \\
\hline Świętokrzyskie & 29.64 & 18.50 & 12.91 & 10.60 & 12 & 8 & 64.2 \\
\hline Warmian-Masurian & 31.94 & 21.37 & 13.39 & 11.07 & 15 & 12 & 65.4 \\
\hline Greater Poland & 27.29 & 18.32 & 12.44 & 10.16 & 4 & 5.5 & 62.8 \\
\hline West Pomeranian & 29.40 & 21.10 & 13.10 & 10.39 & 11 & 9.5 & 64.7 \\
\hline
\end{tabular}

Source: Own study, based on: (Bank). 
Over the analyzed years, there had been an increase in the number of computers with the Internet access, which in turn translated into a decrease in the number of children per one unit. In 2003 in Poland, there were fewer than 43 primary school pupils and fewer than 28 junior high school students per one computer. Ten years later, the comfort of working on computers at both levels of education has improved significantly, as the number of children using one computer has fallen to 10 .

Among the provinces in which the decrease in the number of children per one computer in primary schools was the largest, the following should be mentioned: Świętokrzyskie and Opole - decrease by over $80 \%$, and Podkarpackie - decrease by $79 \%$. At the lower secondary, among provinces, in which the number of student groups working on one computer decreased the most, was the Opole again (drop by over $76 \%$ ), Lower Silesia (decrease by 68\%) and Lublin (decrease by 67\%). It should be noted that provinces, in which the fall in the number of students per one computer was the highest, at the same time ranked high in the amount of subsidies from the area of science and education per capita (Table 1). The Świętokrzyskie province (first place in the ranking), Podkarpackie (third place in the ranking) and Lublin (5th place in the ranking) should be mentioned here.

Another indicator, considered to be a tool helpful in assessing the level of human capital, can be the results obtained by students at various levels of education. In international comparisons, the results of PISA ${ }^{12}$ results, collected over many years in European countries, will be of help. These results are used not only to assess the effectiveness of education systems in individual countries, but also allow to assess the level of students' competences and knowledge in such key areas as: mathematics, natural sciences or reading comprehension skills, and text interpretation.

In each of the areas examined, starting from the year 2006, Polish students were getting better and better results, which allowed them to rank in the top of European countries in 2012. They took the third place in natural sciences and reading skills, after the students from Finland (whose education system is considered the best in the world), and from Estonia in the natural sciences, and Ireland in reading skills. At the same time, attention should be paid to the scale of progress that Polish students recorded in 2009 and 2012, compared to previous years in which the tests were carried out.

In the regional dimension, a useful tool for assessing the level of knowledge of Polish students can be the results of lower secondary school tests written at the end of middle school. They consist of two basic parts: humanities and mathematical-science, and a foreign language knowledge test (English). Looking at these results over the analyzed years, attention should be paid to very good results (above the average for Poland)

12 PISA - The International Student Skills Assessment Program - implemented by an international consortium overseen by the OECD (Organization for Economic Cooperation and Development) and representatives of member countries. It is the largest international examination of students' skills in the world. It is implemented every 3 years since 2000 in all OECD countries, as well as in several dozen partner countries. In each edition of the research, one of the areas: reading and interpretation, mathematical skills, reasoning in natural sciences - is a leading field. The OECD PISA is a study of 15 -year-olds - students who completed the study in the year preceding the age of 15. In PISA 2015, participated over 500,000 students from 72 countries and regions. (Sitek). 
in provinces commonly classified as the so-called 'Poland B', i.e. located in the eastern part of the country.

\section{Chart 5. Place of Polish students among European Union countries according to the results of PISA research in mathematics, natural sciences and reading and interpretation skills in 2003, 2006, 2009 and 2012*}

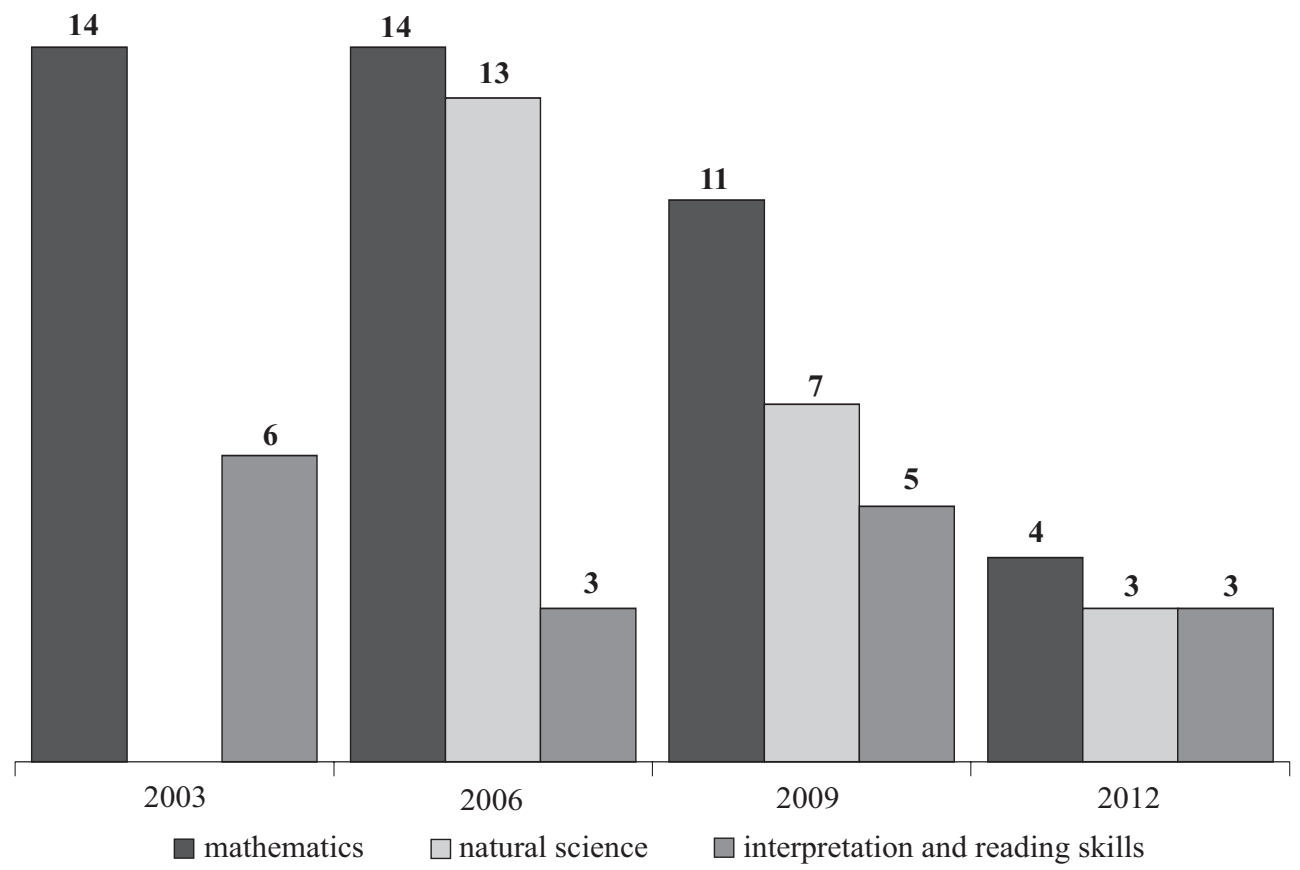

* Mathematics: 2003 - 20 countries in the ranking, in the remaining years 26 countries in the ranking; natural sciences: 26 countries in the ranking; reading skills: 2003 - 19 countries in the ranking, 2006 and 2012 -26 countries in the ranking, $2009-25$ countries in the ranking.

Source: Wyniki, 2013, p. 14, 18, 22.

In the mathematics and natural sciences in 2005, in addition to the Mazovian province, the leaders were also: Lesser Poland, Świętokrzyskie and Lublin provinces. In 2009, the Lesser Poland and Podlasie were again the leaders. In 2012, next to the traditional leader, Lesser Poland, the Podkarpackie and Podlasie provinces were also ranked high. In the case of test results in the humanities and social sciences, the situation was similar. In all the analyzed years (2005, 2009 and 2012), Lesser Poland was at the top of the rankings, in 2005 together with the Silesian and Podkarpackie provinces, and in 2009 and 2012 with the Podkarpackie province (Bank). It should be emphasized that these provinces were at the same time leaders in terms of the value of EU subsidies in the area of science and education per one inhabitant.

An important determinant of the development of human capital is the scale of the universality of lifelong learning, that is, the continuous acquisition, development and renewal of skills in adulthood. It is worth looking at how in this respect the situation has changed in Poland (and provinces) over the years. 
Adults (aged 25-64) participating in training and education in \% in selected years

\begin{tabular}{|l|c|c|c|c|c|c||}
\hline \multicolumn{1}{|c|}{ Province } & $\mathbf{2 0 0 7}$ & $\mathbf{2 0 0 9}$ & $\mathbf{2 0 1 2}$ & $\begin{array}{c}\text { Ranking } \\
\text { in 2007 }\end{array}$ & $\begin{array}{c}\text { Ranking } \\
\text { in 2012 }\end{array}$ & $\begin{array}{c}\text { Ranking - value of } \\
\text { subsidies per capita }\end{array}$ \\
\hline Poland & 5.1 & 4.7 & 4.5 & - & - & - \\
\hline Lower Silesian & 5.7 & 5.0 & 3.8 & 3 & 7 & 16 \\
\hline Kuyavian-Pomeranian & 3.9 & 4.3 & 4.5 & $\mathbf{1 2}$ & $\mathbf{5 . 5}$ & $\mathbf{1 0}$ \\
\hline Lublin & 6.0 & 4.8 & 5.2 & $\mathbf{2}$ & $\mathbf{3}$ & $\mathbf{5}$ \\
\hline Lubusz & 4.0 & 3.3 & 2.9 & $\mathbf{1 1}$ & $\mathbf{1 5}$ & $\mathbf{2}$ \\
\hline Łódź & 3.5 & 3.9 & 3.1 & $\mathbf{1 6}$ & $\mathbf{1 3}$ & $\mathbf{1 3}$ \\
\hline Lesser Poland & 4.5 & 4.1 & 4.6 & $\mathbf{7 . 5}$ & $\mathbf{4}$ & $\mathbf{9}$ \\
\hline Mazovian & 8.3 & 7.3 & 6.9 & $\mathbf{1}$ & $\mathbf{1}$ & $\mathbf{1 4}$ \\
\hline Opole & 4.5 & 4.9 & 3.6 & $\mathbf{7 , 5}$ & $\mathbf{9 . 5}$ & $\mathbf{8}$ \\
\hline Podkarpackie & 3.8 & 3.0 & 3.0 & $\mathbf{1 3}$ & $\mathbf{1 4}$ & $\mathbf{3}$ \\
\hline Podlasie & 4.2 & 4.0 & 4.1 & $\mathbf{9}$ & $\mathbf{8}$ & $\mathbf{6}$ \\
\hline Pomeranian & 4.9 & 5.0 & 6.1 & $\mathbf{6}$ & $\mathbf{2}$ & $\mathbf{1 1}$ \\
\hline Silesian & 5.1 & 4.2 & 4.5 & $\mathbf{5}$ & $\mathbf{5 . 5}$ & $\mathbf{1 2}$ \\
\hline Świętokrzyskie & 3.6 & 4.2 & 3.3 & $\mathbf{1 5}$ & $\mathbf{1 1}$ & $\mathbf{1}$ \\
\hline Warmian-Masurian & 3.7 & 4.4 & 2.8 & $\mathbf{1 4}$ & $\mathbf{1 6}$ & $\mathbf{4}$ \\
\hline Greater Poland & 4.1 & 3.7 & 3.6 & $\mathbf{1 0}$ & $\mathbf{9 . 5}$ & $\mathbf{1 5}$ \\
\hline West Pomeranian & 5.3 & 5.3 & 3.2 & $\mathbf{4}$ & $\mathbf{1 2}$ & $\mathbf{7}$ \\
\hline \hline
\end{tabular}

Source: Own study, based on: Kapitat, 2011, 2016, p. 196 (year 2010), p. 149 (year 2015).

The analysis of data contained in Table 4 allows for the formulation of several conclusions. First of all, attention should be paid to the very low percentage of adults above 25 years of age raising their qualifications in the total population in all the years studied. In this respect, Poland is unfortunately in the group of European countries with the lowest values of this indicator. In comparison to such countries as Denmark (31.6\%), Sweden (27\%), Finland (24.5\%), or the Netherlands and the United Kingdom (over 16\%) (GUS, Osoby doroste...), Poland is very unfavorable.

Secondly, higher values for those relating to Poland were obtained by provinces in which there is a large and demanding labor market concentrated around the most dynamically developing urban agglomerations, such as Warsaw, the Tri-City agglomeration or Cracow.

Thirdly, financial resources from the European Union acquired for the development of science and education did not affect the increase in the percentage of adults raising their qualifications through continuing education.

\section{Summary}

EU Structural Funds played a significant role in the development of the Polish science and education sector in 2004-2006. The largest number of projects was co-financed from the European Regional Development Fund - 1,950 projects, however the European Social Fund donated the largest financial resources in the form of subsidies -2.77 billion zł. The level of investment implementation in individual provinces varied, but the number of completed projects does not translate into the value of EU subsidies per cap- 
ita in individual regions. Although the largest number of projects was contracted for implementation in Mazovia, Silesia and Greater Poland, and in those provinces the largest grant value for projects was obtained, the highest value of subsidies per capita was achieved in Świętokrzyskie, Lubusz, Podkarpackie, Warmia and Masuria, and Lublin. In the audited period, only $17.2 \%$ of the number of projects contracted for implementation in Mazovia was carried out in the Świętokrzyskie province.

Funds obtained from the European Union in the years 2004-2006 in the area of science and education supported Polish universities, schools and kindergartens contributing to their better equipment and functioning. This can be testified by the data on pre-school education presented above, which indicate a significant improvement in children's access to this form of education, in particular those children from rural areas (Table 2). The comfort of computer science teaching in Polish primary and junior high schools has also increased, thanks to the reduction in the number of students using one computer with the Internet access (Table 3).

Expanding the opportunities for participation in pre-school education, and reducing digital exclusion among Polish children, have undoubtedly contributed to the growth of their knowledge, skills and competences. Their clear reflection are the excellent results of Polish students in international PISA tests, both in mathematical and natural sciences, as well as in the humanities. Significantly, these results improved radically after Poland's accession to the European Union (Chart 5).

The increase in the level of human capital in Poland may also be illustrated by changes in the structure of the adult population of Poland according to the level of education. The direction of these changes in recent years is clearly positive and is reflected in the decrease in the share of the number of people with the lowest education (primary and lower secondary/junior high) in the total number of adult population and a significant increase in shares of people with university education (Chart 4).

The above-mentioned positive tendencies mean an increase in the level of human capital in Poland. It is determined by a number of factors, including financial resources obtained from the European Union for the science and education sector. The structural funds contributing to its development can be demonstrated by the data on changes in the level of human capital in the regional cross-section (divided into 16 provinces) presented in this report, compiled with the ranking of provinces in terms of the subsidy received from the EU funds per capita. Provinces, which obtained high positions in this ranking, at the same time could boast the highest dynamics of access to pre-school and IT education or the best results of junior high school tests in the country.

What should be emphasized - the process of implementing European funds in the area of science and education in Poland continues and requires further analysis. In the financial perspective of 2007-2013, 22,407 projects were contracted for implementation, and in the programming period 2014-2020, there are already 1,200. Therefore, further changes in the level of human capital in Poland should be expected.

\section{Bibliography}

Czajkowski Z. (2012), Kapitał ludzki - pojęcie i miary, "Prace i Materiały Instytutu Gospodarki Światowej”, no. 312.

Domański S. R. (1993), Kapitał ludzki i wzrost gospodarczy, Warsaw. 
GUS (Central Statistical Office), Bank Danych Lokalnych, www.bdl.stat.gov.pl, 29.04.2017.

GUS (Central Statistical Office), Bank Danych Lokalnych, www.stat.gov.pl/bdl/, 29.05.2017.

GUS, (2011, 2016) (Central Statistical Office), Kapitat Ludzki w Polsce, rok 2010 i 2015, Warsaw.

GUS (Central Statistical Office), Osoby doroste uczestniczace w ksztatceniu i szkoleniu, www.stat.gov. pl, 06.06.2017.

Kleinowski M., Piechowicz M., Sikora-Gaca M. (2016), Fundusze i programy UE wspierające przedsiębiorstwa w perspektywie finansowej 2014-2020, Warszawa.

Król H., Ludwiczyński A. (2006), Zarzadzanie zasobami ludzkimi. Tworzenie kapitalu ludzkiego organizacji, Warsaw.

Kusińska U. (2014), Fundusze europejskie w edukacji. Wybrane aspekty programu unijnego „Uczenie się przez całe życie” Comenius, in: Fundusze europejskie w teorii i praktyce. Edukacja, gospodarka, kultura, społeczeństwo, eds. M. Sikora-Gaca, U. Kosowska, Warsaw.

Mapa dotacji UE, www.mapadotacji.gov.pl, 25.05.2017

Miciuła I., Miciuła K. (2015), Metody pomiaru wartości kapitału ludzkiego, „Współczesne Problemy Ekonomiczne", no. 11.

Ministerstwo Rozwoju Regionalnego (2013), Sprawozdanie końcowe z realizacji Narodowego Planu Rozwoju na lata 2004-2006, Warsaw.

OECD PISA (2013), Wyniki Badania 2012 w Polsce, ed. M. Fedorowicz, Warsaw.

Rządowa Rada Ludności (2007), Sytuacja demograficzna Polski. Raport 2006-2007, Warsaw.

Sikora-Gaca M., Piechowicz M., Kleinowski M. (2018), Zarzadzanie funduszami europejskimi w Polsce, Warszawa.

Sitek M. (ed.), Program Międzynarodowej Oceny Umiejętności Uczniów. Wyniki badania 2015 w Polsce, www.ide.edu.pl, 25.05.2017.

Więziak-Białowolska D. (2011), Ocena kapitału ludzkiego oraz jego zróżnicowanie demograficzne, społeczne i ekonomiczne $w$ Polsce $i$ województwie podkarpackim - analiza porównawcza, "Studia Regionalne i Lokalne", no. 2(44).

\section{Ocena zmian poziomu kapitału ludzkiego w Polsce w kontekście wykorzystania funduszy europejskich na projekty $z$ zakresu nauki i edukacji zakontraktowane do realizacji w latach 2004-2006}

\section{Streszczenie}

W artykule przeanalizowano 2947 projektów z obszaru nauki i edukacji realizowanych przy udziale funduszy strukturalnych w Polsce, w latach 2004-2006. Podsumowano inwestycje współfinansowane z Europejskiego Funduszu Rozwoju Regionalnego, Europejskiego Funduszu Społecznego i Europejskiego Funduszu Orientacji i Gwarancji Rolnej. Zweryfikowano dane dotyczące 2947 projektów w podziale na poszczególne województwa. Dzięki temu wyodrębniono regionalnych liderów pod względem liczby złożonych projektów i pozyskanych środków finansowych w latach 2004-2006. Określono kwotę dotacji z UE do projektów z obszaru nauki i edukacji w Polsce per capita. Dane te skonfrontowano z wybranymi wskaźnikami rozwoju kapitału ludzkiego w latach 2003, 2006, 2009 i 2012 w celu oceny wpływu funduszy europejskich w obszarze nauki i edukacji na poziom kapitału ludzkiego w Polsce.

Słowa kluczowe: Polska, nauka i edukacja, fundusze strukturalne, dofinansowanie, kapitał ludzki 